\title{
Electrochemical Power Generation from Carbon in Fuel Cell with Molten Hydroxide Electrolyte
}

\author{
Meselu Eskezia* \\ College of Natural and Computational Science, Department of Chemistry, Oda Bultum University, Chiro, \\ Ethiopia
}

*Corresponding Author: Meselu Eskezia, College of Natural and Computational Science, Department of Chemistry, Oda Bultum University, Chiro, Ethiopia

\begin{abstract}
Carbon is a unique element that possesses both electrical and structural properties that make an ideal material for uses fuel cells process. The direct carbon fuel cell (DCFC) is a special type of high temperature fuel cell that directly uses a solid carbon as the anode. The direct electrochemical power generation from carbon in fuel cells uses molten hydroxide electrolyte and carbon is electrochemically directly oxidized to generate power without the need for combustion or reforming process. Molten hydroxides are very important electrolyte in direct carbon fuel cell. They have a higher ionic conductivity and higher activity of carbon electrochemical oxidation. Depending on its compelling cost and performance advantages, the use of molten hydroxide electrolytes has been rejected by researchers, because of the potential formation of carbonate salt in the cell. In DCFC anode acts as an electrode which needs to have low resistance and high electron conductivity and also as a reactant which will be consumed during direct electrochemical power generation from carbon fuel cell..

The performance of DCFC is influences by various operating conditions including cathode inlet air flow rate, electrolyte temperature and fuel particle size. The operation of DCFC could be improved by proper selection of the fuel particle size. Larger the fuel particle size, the slower the cell voltage and as the electrolyte temperature increase, the electrical parameters also increase and the corrosion of the fuel cell reduced by the formation of oxide layers that determine reliable and continuous operation of the fuel cell.
\end{abstract}

Keywords: Molten hydroxide; direct carbon fuel cell; fuel cell; electrochemical treatment; Carbon anode; Air cathode

\section{INTRODUCTION}

Carbon possesses a unique characteristic of both electrical and structural properties of that make an ideal material that uses for fuel cell fabrication. Carbon is unique element among the chemical elements that can exist in various allotropes form. The softest, naturally occurring form is graphite. Only three of the valence electron in the carbon atom is involved in forming $\mathrm{sp}^{2}$ hybrid bond that means the fourth electron forms a pi-bond. This is because of pi electrons are mobile, graphite is a good electrical conductor, which is used to for fuel cell application. The pi electrons in graphite can also react with other elements without change the layer structure. However, some reacting atoms or molecules can interact between the layers, and cause either decrease or increase in electrical conductivity [1].

The DCFC is a power generation device converting the chemical energy of carbon directly into electricity by electrochemical oxidation of the fuel. There are different types of fuel cells, such as solid oxide fuel cells, hydrogen fuel cells, alkaline fuel cells, phosphoric acid fuel cells and molten carbonate fuel cells. The basic structure of direct carbon fuel cell is identical to other fuel cells. All cells consist of a cathode and anode separated by electronically insulating but ionically conducting electrolyte. The difference between DCFC and other fuel cells is that the anode chamber is supplied with a solid carbonaceous fuel (e.g. coals, biomass, active carbon, graphite etc) that is oxidized directly at the electrode surface. Among other fuel cell technology, DCFC is relatively simple and require expensive preparation of any gaseous fuel as well as all carbonaceous substances [2].

Among the two forms of carbon, the highly organized carbon form is graphite, is used as the benchmark because of its availability and stability. DCFCs has a potential to convert chemical energy of carbon directly into electricity without applied any external force (like combustion, reforming process and gasification) [3]. 
Direct carbon fuel cell (DCFC) is a high temperature fuel cell using carbon materials directly as the anode. DCFC has unique attractive characteristics. Firstly, it provides a great thermodynamics advantages than other fuel cell types like MCFC, PAFC and AFC. Secondly, it should be twice as fuel efficient as coal-fired power plants, resulting in reduced carbon dioxide emission per unit generated electricity [4].

A fuel cell that uses carbon as a fuel is called direct carbon fuel cell (DCFC). Several researcher investigated that the use of carbon as a fuel at a temperature of $1000^{\circ} \mathrm{C}$ using a solid oxide fuel cell (SOFC) with solid yttria-stablized zirconia as the electrolyte. But the results obtained with SOFC approach only slightly more than the modest one [5]. The direct carbon fuel cell (DCFC) is a novel high temperature fuel cell, is drawing to increasing attention due to its high conversion efficiency with low pollution [6].

The latest development in DCFC is to utilize highly reactive carbon particulates dispersed in the molten electrolyte, between the anode and cathode at high temperature. The anode and cathode reactions in this work may be expressed by the following reaction,
Anode reaction:
$\mathrm{C}+2 \mathrm{CO}_{3}^{2-} \rightarrow 3 \mathrm{CO}_{2}+4 \mathrm{e}^{-}$
Cathode reaction:
$\mathrm{O}_{2}+2 \mathrm{CO}_{2}+4 \mathrm{e}^{-} \rightarrow 2 \mathrm{CO}_{3}^{2-}$
Over all reaction:
$\mathrm{C}+\mathrm{O}_{2} \rightarrow \mathrm{CO}_{2}$

It occurs with the flow of four electrons from the anode to cathode.

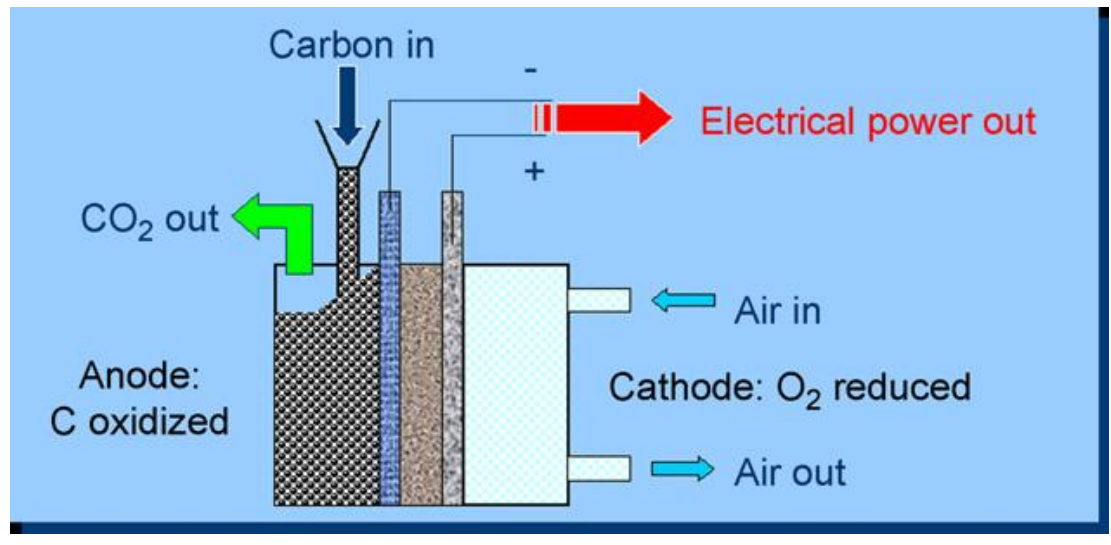

Figure1. Schematic diagram of a DCFC configuration

Researchers pointed out the anode in DCFC are simply a current collector and the electrochemical reaction occurs between carbon and carbonate ions in the electrolyte environment. The carbon fuel was placed on the anode surface before the fuel cell was assigned. Typical DCFCs operating temperature ranges from $650^{\circ} \mathrm{C}$ to $900^{\circ} \mathrm{C}$ and its performance is strongly dependent on temperatures [7].

\section{Theory of Direct Carbon Fuel Cell with Molten Hydroxide Electrolyte}

\subsection{Advantages of Molten Hydroxide Electrolyte in DCFC}

DCFC is a type of fuel cells that uses molten hydroxide $(\mathrm{NaOH})$ as the electrolyte contained a metallic container, which acts as a cathode. Fuel is fed in to the cell in the form of a rod made from graphite derived carbon dipped into the electrolyte. This fuel rod act as the anode of the cell and air is purged in to the molten salt at the bottom of the container to supply oxygen at the cathode. Typical operating temperatures are in the range $500-650^{\circ} \mathrm{C}[8]$.

There several advantages of molten hydroxide electrolyte over molten carbonate electrolyte (i) molten hydroxide electrolyte are higher ionic (electrical) conductivity. This higher ionic conductivity is achieved require lower temperatures in molten hydroxide than molten carbonate electrolytes,450$650^{\circ} \mathrm{C}$, (ii) molten hydroxide electrolyte is the higher electrochemical properties of carbon, which means the higher anodic oxidation rate and lower over potentials exhibited in the molten hydroxide electrolyte system. The higher ionic conductivity and higher anodic currents enable lower operating temperatures $\left(450-750^{\circ} \mathrm{C}\right)$ and these allow the use of less expensive materials for cell fabrication, (iii) molten hydroxide electrolyte is higher yield of carbon oxidation at the lower melt temperature of the hydroxide system $[9,10]$. 
Molten hydroxide has lower over potentials and greater oxidation rate than molten carbonate. Due to these factors the MHFC to operate at lower temperatures, allowing for cheaper materials to be used for cell fabrication and electrodes [11]. At lower operating temperature of the hydroxide melts, the major product of carbon oxidation is $\mathrm{CO}_{2}$. It indicates that four electrons exchanged per one carbon atom but the higher temperatures of the carbonate melt, the major product is $\mathrm{CO}$ and shows only two electrons are exchanged per one carbon atom. The main problem in commercialization a typical MCFC is corrosion instability of the $\mathrm{NiO}$ cathode at $650^{\circ} \mathrm{C}$ over time [9].

The dissolution of $\mathrm{NiO}$ in a carbonate electrolyte is accelerated by the present $\mathrm{CO}_{2}$ and $\mathrm{O}_{2}$ gases and by higher temperatures in the MCFC. But in molten hydroxide electrolyte, the dissolution of $\mathrm{NiO}$ is expected to be significantly lower because of the lower temperature $\left(<500^{\circ} \mathrm{C}\right)$ and the absence of $\mathrm{CO}_{2}$ gas from the inlet air and $\mathrm{Ni}$ has to be a chemically stable materials in molten hydroxide environment. Nickel containers are used to produce anhydrous $\mathrm{NaOH}$ by concentrating an aqueous solution and by heating that solution up to $500^{\circ} \mathrm{C}$ to produce the desired $\mathrm{NaOH}$ melt. Furthermore, Nickel is used as the anode in sodium production from the resulting sodium hydroxide melt [10].

\subsection{The role of molten hydroxide electrolyte in direct carbon fuel cell}

The main role of molten hydroxide electrolyte in the DCFC is to create a medium through which carbonate ions can travel from the cathode to the anode. Electrolytes can also act as a kind of filter that used to prevent undesirable ions or electrons from disrupting the desired chemical reactions. In the aqueous alkaline fuel cell, the electrolyte consists in a liquid mixture that presents a good ionic conductivity. The molten hydroxide electrolytes present the advantages of higher electrochemical activity of carbon and the operating temperatures of the fuel cell can be lowered and consequently reduce the corrosion problem [13].

Different experiments have shown that, in order to achieve the desired ionic conductivity, the electrolyte mixture must be heated approximately $150^{\circ} \mathrm{C}$ above its melting temperature. The melting temperatures of electrolytes are highly dependent on their composition [7]. Electrochemical reactions involved with the molten hydroxide electrolyte DCFC are shown below,

Anode: $\mathrm{C}+4 \mathrm{OH}^{-} \rightarrow 2 \mathrm{H}_{2} \mathrm{O}+\mathrm{CO}_{2}+4 \mathrm{e}^{-}$

Cathode: $\mathrm{O}_{2}+2 \mathrm{H}_{2} \mathrm{O}+4 \mathrm{e}^{-} \rightarrow 4 \mathrm{OH}^{-}$

Over all reaction: $\mathrm{C}+\mathrm{O}_{2} \rightarrow \mathrm{CO}_{2}$

\subsection{Conversion of Molten Hydroxide into Molten Carbonate}

Depending on its compelling cost and performance advantages, the use of molten hydroxide has been rejected in the past by DCFC researchers, due to the potential formation of carbonate salt in the cell due to the absorption of $\mathrm{CO}_{2}$ by the hydroxide melt. Because of the conversion of hydroxide into carbonate, the above discussed advantages of hydroxide electrolyte is lost. But the carbonate formation can be prevented by reducing carbonate formation in DCFC is to ensure a high water content of the electrolyte [9].

Conversion of hydroxide into carbonate formation can be expressed by using chemical process represented by the following reaction,

$$
2 \mathrm{OH}^{-}+\mathrm{CO}_{2} \leftrightarrow \mathrm{CO}_{3}{ }^{2-}+\mathrm{H}_{2} \mathrm{O}
$$

And also an electrochemical process taking place at the carbon anode given by:

$$
\begin{aligned}
& \mathrm{C}+6 \mathrm{OH}^{-} \rightarrow \mathrm{CO}_{3}{ }^{2-}+3 \mathrm{H}_{2} \mathrm{O}+4 \mathrm{e}^{-} \\
& 6 \mathrm{OH}^{-} \leftrightarrow 3 \mathrm{O}^{2-}+3 \mathrm{H}_{2} \mathrm{O} \text { (fast) } \\
& \mathrm{C}+3 \mathrm{O}^{2-} \rightarrow \mathrm{CO}_{3}{ }^{2-}+4 \mathrm{e}^{-} \text {(slow) }
\end{aligned}
$$

The rate of carbonate formation depends upon the $\mathrm{O}^{2-}$ and water concentration. The prevention or significantly reduction of carbonate formation was made by ensuring a high water content of the electrolyte which causes reactions (1) and (3) to shift backward to decrease the carbonate formation. The high water content in the melt is simply achieved by maintaining a humid atmosphere above the melt [10]. High water content in the electrolyte has advantages effect on DCFC performance. During the reducing carbonate formation, high water content increases the ionic conductivity of the melt. Water in hydroxide melt helps in reducing the corrosion rate of nickel, iron and iron oxide. But the corrosion rate of these metals depends on the peroxide content of the melt [9]. 
The molecular oxygen is oxidized in fused hydroxide and reacts with oxide and hydroxide ions producing superoxide and peroxide ions. The corrosion rate of these metals depends on the peroxide content of the melt the electrolyte. The concentration of these ions is determined by the following equilibrium,

$$
\begin{aligned}
& \mathrm{O}_{2}+4 \mathrm{OH}^{-} \leftrightarrow 2 \mathrm{O}_{2}^{2-}+2 \mathrm{H}_{2} \mathrm{O} \\
& 3 \mathrm{O}_{2}+4 \mathrm{OH}^{-} \leftrightarrow 4 \mathrm{O}^{-}+2 \mathrm{H}_{2} \mathrm{O}
\end{aligned}
$$

From these reactions, the water vapour pressure may increase and reduce the oxides content of the melt with reduces the corrosion rate simultaneously. There are some oxides $\mathrm{SiO}_{2}, \mathrm{ZnO}$ and $\mathrm{MgO}$ might be help in preventing the conversion of hydroxide in to carbonates [9].

\section{Electrode Reaction in Molten Hydroxide EleCtrolyte}

\subsection{Electrochemical Oxidation of Carbon}

Electrochemical oxidation of carbon requires a high temperature because of its slow (inactive) kinetics and is generally performed on molten hydroxide electrolyte [8]. Reactions species can be performed on molten hydroxide electrolyte depend on the acid-base properties of the melts and the concentration. By applying heat, the molten hydroxide electrolyte loses water, the concentration of $\mathrm{OH}^{-}$ions is decrease and such melt is called basic melt are metal cation $\mathrm{Me}^{+}, \mathrm{O}_{2}^{-}, \mathrm{O}^{2-}, \mathrm{O}_{2}{ }^{2-}$ anions and molecular, $\mathrm{O}_{2}$ [9]. But in molten hydroxides with a high water content is called acidic melts equilibrium reaction (5) and (6) are shift to the left, resulting in a very low concentration of ions containing only oxygen $\mathrm{O}^{2-}, \mathrm{O}_{2}{ }^{2-}$ and $\mathrm{O}_{2}^{-}$ions. So, the dominant species in molten hydroxide melts with high water content are $\mathrm{Me}^{+}, \mathrm{OH}^{-}$ ions, $\mathrm{O}_{2}$ and $\mathrm{H}_{2} \mathrm{O}$ molecules [8].

The reaction mechanism of anodic oxidation of carbon is unknown and most likely is very complex due to involve up four electrons, two stable reaction products such as, $\mathrm{CO}$ and $\mathrm{CO}_{2}$ and also many reaction intermediates are produced [10]. Therefore, in acidic melts, the anodic oxidation of carbon is the primary reaction product is $\mathrm{CO}_{2}$ by using the following equation,

$$
\mathrm{C}+4 \mathrm{OH}^{-} \rightarrow \mathrm{CO}_{2}+2 \mathrm{H}_{2} \mathrm{O}+4 \mathrm{e}^{-}
$$

The presence of $\mathrm{CO}$ in the product gas mixture can be explained by the reaction between the gaseous $\mathrm{CO}_{2}$ and solid carbon to form gaseous $\mathrm{CO}$, can be expressed as,

$\mathrm{C}+\mathrm{CO}_{2} \leftrightarrow 2 \mathrm{CO}$

The equilibrium constant of the equation (8) was determined by function of temperature. So, it was found that the dominant gaseous species at a temperature of above $750^{\circ} \mathrm{C}$ is $\mathrm{CO}$, whereas at lower temperatures the dominant gaseous species is $\mathrm{CO}_{2}$. The results indicate that other mechanism may be responsible for the formation of $\mathrm{CO}$ during anodic oxidation of carbon [10]. Based on the experimental findings, different review proposed that a reaction path way consists of two electrochemical steps, (i) involves the electrochemical oxidation of carbon to $\mathrm{CO}$ and (ii) involves further electrochemical oxidation of $\mathrm{CO}$ molecule to $\mathrm{CO}_{2}$ at higher over potentials [9].

If the anodic over potential is not high enough with high surface area carbon anode, $\mathrm{CO}$ will not be further oxidized into $\mathrm{CO}_{2}$ resulting in a high $\mathrm{CO} / \mathrm{CO}_{2}$ ratio. It results that the flow of current density which is turn low because of first high surface area at carbon particles close to current collector and high electrical resistance through the anode slurry because of weak particle to particle contact resulting in almost no activity of carbon particle far from the current collector [10]. But, at higher current densities, the over potentials are high, resulting in the oxidation of $\mathrm{CO}$ to $\mathrm{CO}_{2}$ and very low $\mathrm{CO} / \mathrm{CO}_{2}$ ratio [9].

\subsection{Cathodic Reduction of Oxygen}

The mechanism of the cathodic reaction is also not completely understood still now. Researcher showed that, oxygen reduction in molten hydroxide has no practically experimental work. The analogy of oxygen reduction with aqueous alkaline solutions one can assume temporarily that stoichiometric reaction for oxygen reduction in hydrated molten hydroxides is the same as in aqueous solutions,

$\mathrm{O}_{2}+2 \mathrm{H}_{2} \mathrm{O}+4 \mathrm{e}^{-} \rightarrow 4 \mathrm{OH}^{-}$

Therefore, oxygen reduction at cathode may involve electrons per oxygen molecule depending on the reduction product. So, the concentration of superoxide and peroxide ions in hydrated (acidic) melts is very low, one cannot damages that equation (9), which is the oxygen reduction reaction in aqueous 
solutions is the dominant reaction in molten hydroxide in direct carbon fuel cell. Superoxide and peroxide oxide ions may also appear as reactants in oxygen reduction at cathode. According to oxygen reduction at cathode is expressed by,

$\mathrm{O}_{2}^{2-}+2 \mathrm{H}_{2} \mathrm{O}+2 \mathrm{e}^{-} \rightarrow 4 \mathrm{OH}^{-}$

$\mathrm{O}_{2}^{-}+2 \mathrm{H}_{2} \mathrm{O}+3 \mathrm{e}^{-} \rightarrow 4 \mathrm{OH}^{-}$

The result measured only the limiting current of oxygen reduction in hydroxides but not study the electrode reaction mechanism of oxygen [10].

\section{Operating Principles of Direct Carbon Fuel Cell}

DCFCs are electrochemical methods that convert the chemical energy in carbon directly into electricity without any combustion. It is the direct electrochemical oxidation of solid carbon at high temperatures $\left(600^{\circ} \mathrm{C}-900^{\circ} \mathrm{C}\right)$. The reactions in DCFC produce pure carbon dioxide, provided high purity carbon is used as a fuel [8].

Researchers at SARA for DCFC on a simple cell design, the use of less expensive materials and achieving cell performance acceptable for scale up. The simple cell design is a modern design based on the use of a nonporous air cathode. The central part of the cell is a cylindrically carbon anode immersed into molten sodium hydroxide, which serve as electrolyte. The molten hydroxide is contained in a cell container, which act as the same as the air cathode [9]. During this time, the air cathode filled with oxygen by introducing the humidified air in to cell melt where as the gas bubbler located at the bottom of the cell. Since the cell does not have a separator, the humidified air bubbles and air dissolved in the melt are direct contact with the two electrodes such as, the graphite anode and oxygen cathode [10].

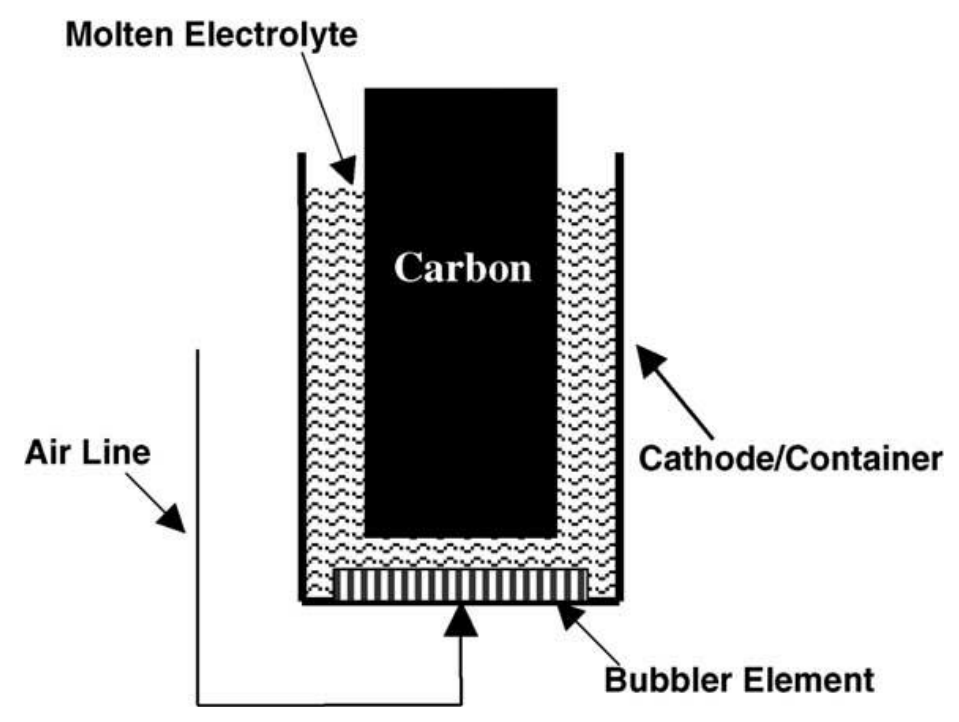

Figure2. Schematic diagram of SARA direct carbon fuel cell

The suitable air cathode materials during DCFC molten hydroxide electrolyte, the materials is inexpensive and corrosion stable that can be used for both the air cathode and cell container. From these materials the researchers found, nickel is the best air cathode material for molten hydroxide electrolyte [7].

\section{Factors Affecting the Performance of Direct Carbon Fuel Cell}

The influence of several operating conditions for the performance of direct carbon fuel cell likes, cathode inlet air flow rate, electrolyte temperature, the size of fuel particle. Several experiments showed that cell performance of DCFC was increased with the cathode inlet air flow rate and cell temperature [2].

\subsection{The Effect of Electrolyte Temperature}

The effect of temperature in the performance of DCFC indicates that the increase of electrolyte temperature brings about increase the electrical parameters of the cell. The fuel cell generated high power density and current was probably they improved conductivity of electrolyte and also to increase the reaction rate. The increased electrolyte temperature not only increases the cell performance but also an impact on the corrosion process that may leads to the shutdown of fuel cells. The current and power densities achieved at a temperature of $773 \mathrm{~K}$ were twice as high result as obtained $673 \mathrm{~K}[3,7]$. 


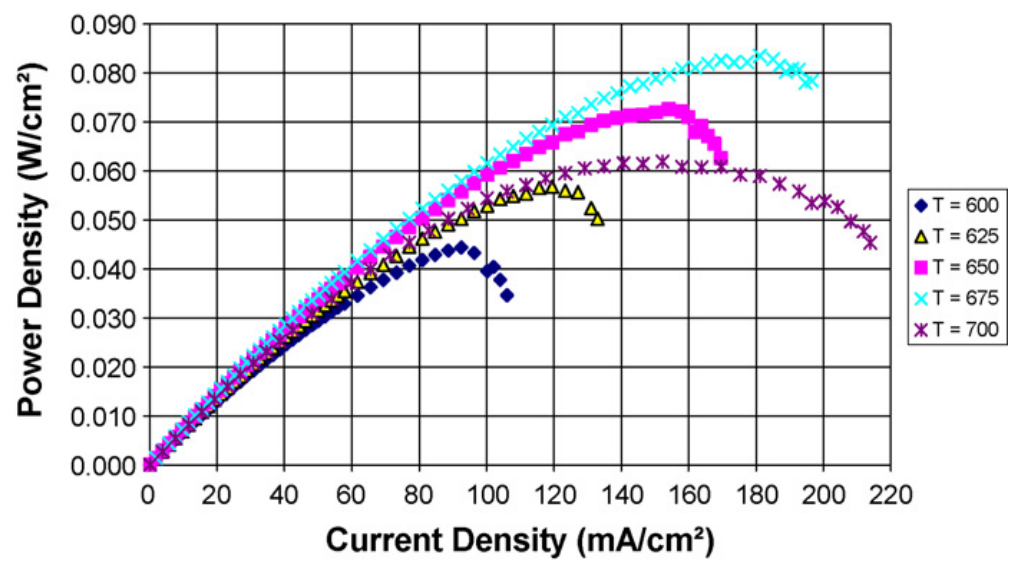

Fig3. Effect of temperature on power density as a function of current density

\subsection{The Effect of Air Flow Rate}

The effect of air flow rate showed that both very small and very large air flow rates to the cathode chamber of the fuel had a negative effect on DCFC electrical performance. The value of the air flow rate affects the deterioration of the performance of DCFC. This may be related to insufficient amount of substrate $\left(\mathrm{O}_{2}\right)$ in the reduction reaction which occurs on the cathode surface. The higher reaction rate, related to higher current generated by fuel cell results in increased demand for the oxygen which is contained in the air fed to the cathode. In other way, very high values make a lot of gas bubbles, which are formed at the surface of the electrode, limited the reaction surface area and also the fuel cell achieves decrease electrical parameters [2].

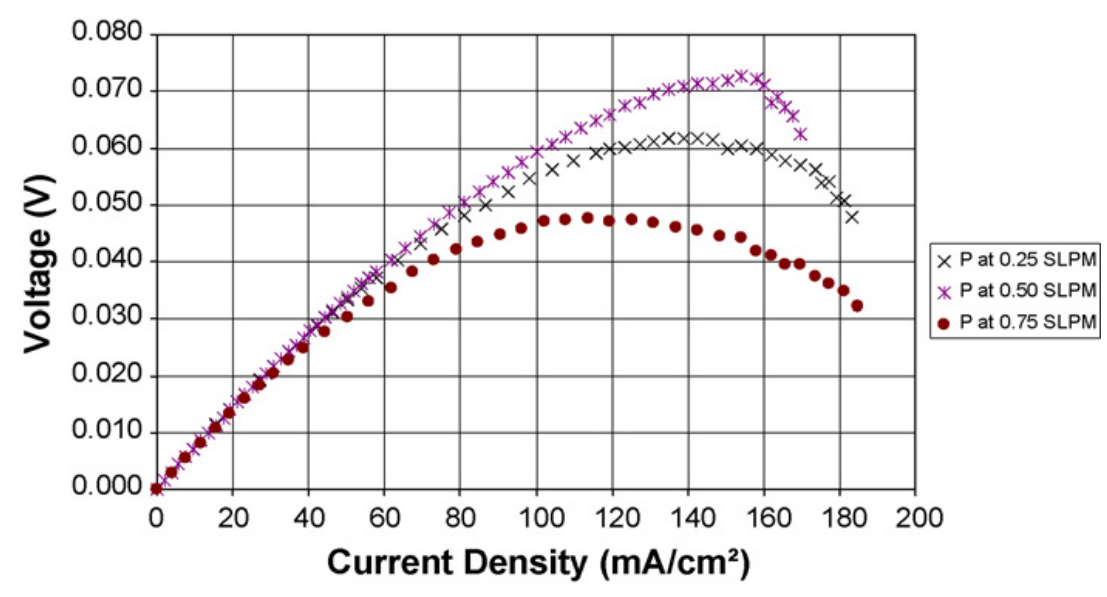

Fig4. Effect of air flow rate on power density using a graphite rod at $675^{\circ} \mathrm{C}$

At a flow rate above the optimum air flow value, the air flowing either very quickly for the reaction to occur optimally or it may be that the bubbles transfer from the float is very large. This cause poorer gas-solid contact at the cathode surface and inhibits the Cathode reaction [2].

\subsection{The Effect of Particle Size of the Fuel}

The size of the fuel particles directly affects the electromotive force. Generally, the larger the fuel particles size the lower the cell voltages. Better performance of the fuel cell obtained by a fuel with a medium particle size compared to the performance of a cell which was fed by a fuel with a smaller particle size may suggest that larger space between the fuel particles positively affect the cell performance [2]. The size of carbon particle decrease, the current density increase to higher values at high electrode potential this is caused by the larger reactive surface area of carbon particles [6].

\subsection{Electrical Conductivity of Carbon Fuel}

The electrical conductivity of carbon fuel is one of the criteria for the performance of the cell. Carbon fuels not only are consumed by the electrochemical reaction but also contact by current collector directly assisted the transfer of electrons. It is well-known that electrical conductivity highly dependent on the degree of graphite structure. A more ordered carbon has a high electrical conductivity but the amorphous structure of carbon is lowest electrical conductivity caused by high porosity [6]. 


\section{CONCLUSION}

Direct electrochemical power generation from carbon in direct carbon fuel cell is a novel high temperature fuel cell and also drawing ever increasing attention due to its high conversion efficiency with low emission. DCFC is the only fuel cell type converting solid carbon into electricity without the need for combustion processes or reforming process. Compared with other type of fuel cells, DCFC has the thermodynamic advantages of near-zero entropy change (high efficiency) at high temperature. DCFC using molten hydroxide electrolyte is most applicable rather than molten carbonate electrolyte due to higher electrical conductivity and the higher electrochemical activity of carbon. Accordingly, the DCFC operated at lower temperatures and thus cheaper materials used to manufacture the cell. The performance of DCFC is increase as the temperature of the electrolyte also increases but decrease as the size of fuel particle increase.

\section{REFERENCES}

[1] Dicks and Andrew L, (2006). "The role of carbon in fuel cells", Journal of Power Sources, 156.2, 128-141.

[2] Kacprzak A, Kobylecki R and Bis Z, (2016). "Efficiency of non-optimized direct carbon fuel cell with molten alkaline electrolyte fueled by carbonized biomass". Journal of Power Sources, 321, 233-240.

[3] Gregory A, John W. Z, and Robert S, (2007). "Evaluation of carbon materials for use in a direct carbon fuel cell."Journal of Power Sources, 168. 111-118.

[4] Chen M, Wang C, Niu X, Zhao S, Tang J, and Zhu B, (2010). "Carbon anode in direct carbon fuel cell." International Journal of Hydrogen energy, 35.7, 2732-2736.

[5] Zecevic S, Edward M. P, and Parviz P (2005). "Direct Electrochemical Power Generation From Carbon in Fuel Cells with Molten Hydroxide Electrolyte." Chemical Engineering Communications, 192.12, 16551670.

[6] De Marco R, Hua Zhu Z, Dicks A, Bradley J, Liu S, and Li X, (2008). "Factors that determine the performance of carbon fuels in the direct carbon fuel cell." Industrial \& engineering Chemistry Research, $47.23,9670-9677$.

[7] Kouchachvili L, and Ikura M, (20011). "Performance of Direct Carbon Fuel cell." International Journal of Hydrogen energy,36.16, 10263-10268.

[8] Badwal, S. P. S, and Giddey S, (2010). "The holy grail of carbon combustion-the direct carbon fuel cell technology." Materials Forum Vol.34, 750-56

[9] Zecevic S, Patton M.E, and Parhami P, (2004). "Carbon-air fuel cell without a reforming process." Carbon, 42.10, 1983-1993.

[10] Rady C.A, Giddey S, Badwal P.S S,and Ladewig.P B, (2012). "Review of fuels for direct carbon fuel cells." Energy \& Fuels, 26.3, 1471-1488.

[11] Cao D, Sun Y, and Wang G, (2007). "Direct carbon fuel cell: fundamentals and recent developments." Journal of Power Sources, 167.2, 250-257.

[12] Pointon K, Lakeman B, Irvine J,Bradley J, and Jain S, (2006). "The development of a carbon- air semi fuel cell."Journal of power sources, 162, 750-756.

[13] Arizaleta L.M, (2012). "Study of the chemistry of the carbon fuel cell electrolyte at near critical conditions." Journal of power sources, $160,852-857$.

Citation: Meselu Eskezia, "Electrochemical Power Generation from Carbon in Fuel Cell with Molten Hydroxide Electrolyte”, International Journal of Advanced Research in Chemical Science, 7(6), pp. 17-23. DOI: https:// doi.org/10.20431/2349-0403.0706003

Copyright: () 2020 Authors, this is an open-access article distributed under the terms of the Creative Commons Attribution License, which permits unrestricted use, distribution, and reproduction in any medium, provided the original author and source are credited. 